\title{
Analysis of drying operation and quality evaluation of crushed meat prepared from three trims of low beef marketing
}

\begin{abstract}
Summary
The objective of this research was to evaluate the performance and quality of three cuts of beef marketing low during the drying process for the preparation of meat crushes. quality (color, $\mathrm{pH}$, aw, chemical composition) of beef cuts glove, neck and lizard cool and their behavior during drying (curves) and the quality of the finished product (color, $\mathrm{pH}$, aw analyzed, chemical composition). Data were evaluated by analysis of variance via. Color and aw in the raw material were within the normal range, while the $\mathrm{pH}$ was varied from 5.92-6.45. In the chemical composition, the cut glove had higher moisture content (76.42\%). Similarly, during drying, this cut, introduced least resistance for water removal, reaching the desired humidity $(25-30 \%)$ in less time $(240 \mathrm{~min})$. With regard to the finished product, differences in physicochemical characteristics, mainly in color they were presented. The chemical composition, both moisture and protein were affected, which varied between the $24.65-28.09 \%$ and $51.70-53.65 \%$ respectively. The three cuts have assessed potential for the production of dried meat products, such as crushed and dried meat.
\end{abstract}

Keywords: beef cuts, dried, crushed meat, quality, chemical composition
Volume 6 Issue 5 - 2019

\author{
Pollorena Gregorio López, Ariana Sainz \\ Melissa Hernandez, Grace Erandy Baez \\ Hernandez, Monica Gamez Luque \\ Higher Technological Institute of Guasave, Mexico
}

Correspondence: Pollorena Gregorio López Higher Technological Institute of Guasave, International Entronque Road to Gap, Ejido El Burrioncito, Mexico, Email gregopollo@gmail.com

Received: August 30, 2019 | Published: Ocotber 29, 2019

\section{Introduction}

Meat is a high-value food for human consumption because it is a good source of essential amino acids and the main source of B vitamins and minerals. Its distinctive flavor, makes it one of the favorite foods by consumers. However, its intrinsic characteristics as a high water activity, slightly acidic $\mathrm{pH}$, carbohydrate availability (glycogen) and amino acids make it an ideal food for microbial growth. ${ }^{1}$ There are different methods for preserving meat. However, drying is one of the most used since ancient times in combination with the salt, to obtain a product with reduced water activity, high nutrient content and does not require refrigeration. ${ }^{2}$ In the northern traditional meat products obtained by drying, such as dried meat botanera dried meat type and type crushes are made. La Machaca beef is a product, which after drying meat, involves a process of crushing or shredded in specialized mill. At present, these products have great demand in the international market ${ }^{3}$ and are made from different longissimus dorsi muscle as, ${ }^{1}$ semimembranosus, psoas major, etc. , which have high marketing as fresh cuts ${ }^{4}$. However, there are muscles that have low marketing and linger on the shelves of major firms of meat, which may have potential for the development of these dry meat products.

\section{Materials and methods}

\section{Feedstock and drying process}

To do this research it was used as raw material from beef cuts three low marketing (gloves, neck and lizard), with an internal temperature of $5^{\circ} \mathrm{C}$ and provided by a local company, meat processing. Thereafter, these pieces were sliced (Tor-King RB-300) $7 \mathrm{~mm}$ thick and distributed in drying trays, so that the samples were not sobrepusieran. Then, salt ( $2.5 \%$ of initial weight) was added manually tending to be distributed evenly. Once distributed and salty meat, dehydrated in a dryer forced convection (NSF, D-20), varying the temperature of $60-90^{\circ} \mathrm{C}$, to a moisture between $25-30 \%$ in the final product. Once the drying period is complete, the samples were cooled to room temperature,

\section{Measuring $\mathrm{pH}$, color and $\mathrm{Aw}$}

The $\mathrm{pH}$ and color measurement was performed both in fresh meat and meat mash. The $\mathrm{pH}$ evaluation was performed by mixing meat and distilled water in a 1: 9 in a beaker, then the mixture was stirred and the electrode potentiometer (HANNA model 211) was introduced previously calibrated. Color was measured on the surface of the sample with a colorimeter (CR-400 MINOLTA KONIKA, Japan). Color measurement included determination of values $L^{*}, a^{*}, b^{*}{ }^{5}$ The water activity was determined as indicated by Rotronic equipment (HP23), where it was first calibrated with standardized solutions and then the sample was read manually.

\section{Drying curves}

Drying curves for each cut were made, taking into account the operating conditions of the process as the initial moisture of the raw material, temperature, relative humidity, air velocity and final product moisture, among others. ${ }^{6}$ At the start of the initial weights for each cut taken and the weight loss was monitored during drying every 30 minutes for three cuts, until a final humidity of $25-30 \%$. Similarly the increase in temperature was monitored throughout the process, until a maximum temperature of $90^{\circ} \mathrm{C}$. Similarly, the results obtained with the yield of each cut was calculated. 


\section{Chemical composition}

The chemical composition was determined both in fresh meat, as in the finished product.

\section{Moisture determination}

The moisture content was evaluated by drying technique oven (Yamato DX402C) at $100^{\circ} \mathrm{C}$ according to the method $934.01,{ }^{7}$ where the amount of water present in the sample was determined.

\section{Determination of fat}

The fat content was performed on the dried sample on a soxhlet extraction using hexane as solvent according to method AOAC $920.39(2000)$

\section{Protein determination}

Protein content was determined on the dry and defatted sample by the method 960.52 with minor modifications, using a digester (Scorpion Scientific A50304) and distiller (Geo-Lab GLFC-108) micro-Kjeldahl (AOAC, 2000).

\section{Determination of mineral}

The determination of mineral was performed as indicated by the 942.05 method, using a muffle (FELISA FE-363) at a temperature of $550^{\circ} \mathrm{C}^{7}$

\section{Experimental design}

Data were analyzed by analysis of variance via under a randomized complete design and the differences between the mean values were estimated by the Tukey test with a confidence level of $95 \%$.

\section{Results and discussion}

\section{Physicochemical characteristics of the raw material}

In Table 1 the physicochemical characteristics of the raw material are shown and can be seen that significant $(\mathrm{p} \leq 0.05)$ is provided between the cuts for most parameters assessed, except aw ( $\mathrm{p} \geq 0.05$ ). Regarding the $L^{*}$ parameter, and cutting Pescuezo glove had higher values (46.32 - 46.9), you lie Lizard the cut had the lowest (42.72). They have been reported lower values for this parameter $(34.4$ - 36.2) in cattle finished under different grazing systems by Oliveira. Regarding the red (a*), difference was found between all cuts ranging from 13.83 to 23.36 for neck and glove. Some researchers have reported values for this parameter ranging from 12.9 to 14.2 in the cutting striploin different cross steers. ${ }^{8}$ These values are below those found in this investigation. The difference in flesh color may be due to various factors such as the amount of fat in the carcass, meat $\mathrm{pH}$, age of the animal, carcass weight, amount of intramuscular fat, etc. ${ }^{9}$ Regarding the $\mathrm{pH}$, the three cuts varied between 5.92 and 6.45. These values are above the normal range from 5.4 to $5.6 .{ }^{10} \mathrm{Aw}$ was between 0.88 to 0.89 for all cuts. carcass weight, amount of intramuscular fat, etc. ${ }^{9}$ Regarding the $\mathrm{pH}$, the three cuts varied between 5.92 and 6.45. These values are above the normal range from 5.4 to $5.6 .^{10} \mathrm{Aw}$ was between 0.88 to 0.89 for all cuts. carcass weight, amount of intramuscular fat, etc. Regarding the $\mathrm{pH}$, the three cuts varied between 5.92 and 6.45. These values are above the normal range from 5.4 to 5.6. Aw was between 0.88 to 0.89 for all cuts.
Table I Physicochemical Characteristics of the raw materials

\begin{tabular}{llll} 
Colour & Neck & Glove & Lizard \\
\hline L* $^{*}$ & $46.9^{\mathrm{a}}$ & $46.32^{\mathrm{a}}$ & $42.72^{\mathrm{b}}$ \\
to* & $13.83^{\mathrm{c}}$ & $23.36^{\mathrm{a}}$ & $19.84^{\mathrm{b}}$ \\
$\mathrm{pH}$ & $5.93^{\mathrm{b}}$ & $5.92 \mathrm{~b}$ & $6.45^{\mathrm{a}}$ \\
aw & 0.89 & 0.89 & 0.88 \\
\hline
\end{tabular}

$a, b, c$, different literal within each row, indicates significant difference ( $p 0.05)$.

\section{Chemical composition of raw material}

Table 2 shows the composition of each cutting sample and observed that the parameters evaluated all cuts showed significant differences $(p \leq 0.05)$ for the indexes. With regard to moisture content, fat and protein is within the normal range for fresh meat, which according Lawrie, ${ }^{11}$ can range from $71-76 \%$ moisture, $17-21 \%$ protein and 1 $7 \%$ fat. The variation in the composition of each muscle depends on various factors mentioned above. The moisture content in the sample is very important for the drying process, since it largely depends on the time required to achieve the desired final product moisture Kucerova et al. ${ }^{12}$ It can be seen that the cut glove had the highest content $76.42 \%$.

Table 2 Chemical composition of the raw materials

\begin{tabular}{llllll}
\hline Cut & Humidity & Grease & Protein & Carbohydrates & Minerals \\
\hline Neck & $74.08 \mathrm{~b}$ & $4.34 \mathrm{a}$ & $17.27 \mathrm{a}$ & $1.22 \mathrm{~B}$ & $3.09 \mathrm{ab}$ \\
Glove & $76.42 \mathrm{a}$ & $1.1 \mathrm{Ib}$ & $17.33 \mathrm{a}$ & $1.17 \mathrm{~b}$ & $3.97 \mathrm{a}$ \\
Lizard & $73.65 \mathrm{~b}$ & $4.43 \mathrm{a}$ & $13.95 \mathrm{~b}$ & $5.76 \mathrm{a}$ & $2.21 \mathrm{~b}$ \\
\hline
\end{tabular}

$a, b$, different literal within each column indicates significant difference ( $p 0.05)$

\section{Drying curves}

Figure 1 shows the drying curves for each meat cut and can be observed that the three presented a similar behavior. However, the cut glove showed a better aptitude for drying than other cuts because it reached the desired final moisture $(24.65 \%)$ in the shortest time. The difference in drying times for the three cuts may be due to various factors intrinsic to each cut. As is the amount of intramuscular fat, amount of connective tissue, among others, since they limit heat transfer to the workpiece. ${ }^{13}$ It can be seen in Table 2, above the cut has less fat $(1.11 \%)$ in composition than the other. the yields obtained for each slice were also evaluated, it highlighted that, a higher moisture content in the sample, the yield increases. Cutting with the highest yield was $31.76 \%$ Lizard, which was equal $(p \geq 0.05)$ the glove with $31.03 \%$. The lowest yield was obtained in $26.31 \%$ Pescuezo cutting.

\section{Physicochemical evaluation of the finished product}

Table 3 shows the results of the physicochemical evaluation of the finished product is. It can be seen that there is significant difference $(p \leq 0.05)$ for all parameters evaluated. The first parameter evaluated was the aw, which is very important as it relates to food spoilage and microbial growth depends on it. ${ }^{14}$ As regards the aw, lizard cuts the glove and showed the highest values (from 0.58 to 0.59 ), while cutting Pescuezo had the lowest with 0.56 . 0.72 - In an investigation by Harper et al. ${ }^{15}$ the aw dehydrated meat products such as reporting values between 0.71 Jerky was evaluated. However values have been 
reported between .59 to .63 for crushing meat produced in Sonora. Another important factor limiting the deterioration of the product is the $\mathrm{pH}$, because it depends on the type of microorganisms that can grow. The more acid $\mathrm{pH}$ obtained in this research was to cut the lizard (5.71), while the highest recorded in others sections (6.26-6.31). Choi et al., (2008) reported $\mathrm{pH}$ values for semidry jerky added with different levels of pork and beef ranging from 5.73 and 5.75, which are close to those obtained in this investigation. Similarly, the color of the product is very important, because it depends largely on consumer acceptance. Can be observed (Table 3) showed significant difference $(\mathrm{p} \geq 0.05)$ both $\mathrm{L}^{*}$, and $\mathrm{a}^{*}$ and $\mathrm{b}^{*}$. The $\mathrm{L}^{*}$ value was obtained higher cutting glove (48.32) which was different from the others. Some researchers report that this parameter decreases during the drying process, reaching values $30.667 \mathrm{~h}$ drying at $55^{\circ} \mathrm{C} .{ }^{16}$ Regarding the value $\mathrm{a}^{*}$, they showed positive values, indicating a tendency toward saturation red. The highest value was presented in the glove (7.55) and neck (8.81) cuts. As $L^{*}$, this parameter decreases drying time and have been reported values for processed meat with different drying methods and dehydrated air samples values of $5^{1}$ were presented. Similarly, for the parameter $b^{*}$, positive values indicating yellow saturation were obtained. The sample with higher saturation of this color was cut glove with 22.38. Some researchers report that this parameter decreases during the drying process, reaching values 30.66 $7 \mathrm{~h}$ drying at $55^{\circ} \mathrm{C} .{ }^{16}$ Regarding the value a*, they showed positive values, indicating a tendency toward saturation red. The highest value was presented in the glove (7.55) and neck (8.81) cuts. As L*, this parameter decreases drying time and have been reported values for processed meat with different drying methods and dehydrated air samples values of $5.16^{1}$ were presented. Similarly, for the parameter $\mathrm{b}^{*}$, positive values indicating yellow saturation were obtained. The sample with higher saturation of this color was cut glove with 22.38 . Some researchers report that this parameter decreases during the drying process, reaching values $30.667 \mathrm{~h}$ drying at $55^{\circ} \mathrm{C}$. Regarding the value $\mathrm{a}^{*}$, they showed positive values, indicating a tendency toward saturation red. The highest value was presented in the glove (7.55) and neck (8.81) cuts. As L*, this parameter decreases drying time and have been reported values for processed meat with different drying methods and dehydrated air samples values of 5.16 were presented. Similarly, for the parameter $b^{*}$, positive values indicating yellow saturation were obtained. The sample with higher saturation of this color was cut glove with 22.38 .

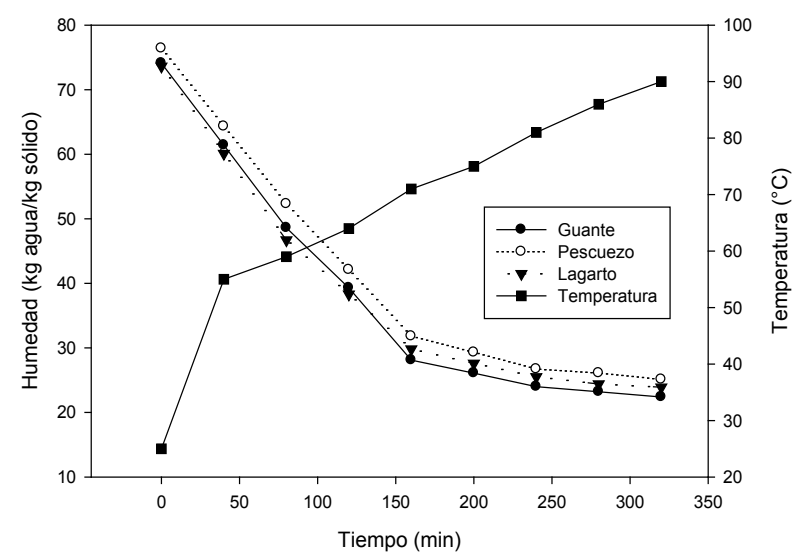

Figure I Registration of the temperature behavior and drying curves of the three cuts analyzed.
Table 3 Physical-chemical evaluation of finished product

\begin{tabular}{llllll}
\hline Cut & Aw & $\mathbf{p H}$ & $\mathbf{L}^{*}$ & to* & $\mathbf{b}^{*}$ \\
\hline Neck & $0.56^{\mathrm{b}}$ & $6.3 \mathrm{I}^{\mathrm{a}}$ & $42.9 \mathrm{I}^{\mathrm{b}}$ & $8.8 \mathrm{I}^{\mathrm{a}}$ & $18.84^{\mathrm{b}}$ \\
Glove & $0.58^{\mathrm{a}}$ & $6.26^{\mathrm{a}}$ & $48.32^{\mathrm{a}}$ & $7.55^{\mathrm{ab}}$ & $22.38^{\mathrm{a}}$ \\
Lizard & $0.59^{\mathrm{a}}$ & $5.7 \mathrm{Ib}$ & $43.60 \mathrm{~b}$ & $6.4 \mathrm{Ib}$ & $15.57 \mathrm{c}$
\end{tabular}

$a, b, c$, different literal within each column indicates significant difference ( $P$ 0.05).

\section{Chemical composition of the finished product}

In Table 4 the results obtained for the chemical composition of the finished product cuts is evaluated. It can be seen that the moisture and protein content were the only parameters that showed significant differences $(p \geq 0.05)$. With respect to the moisture content of the samples, cutting the throat he provided the highest value $(28.09 \%)$, which was statistically similar to the lizard $26.36 \%$. Konieczny et al., ${ }^{16}$ reported different values of moisture during the drying process of jerky beef at $55{ }^{\circ} \mathrm{C}$, reaching a value of $24.55 \%$ for $7 \mathrm{~h}$ of process, which is close to the found in this investigation. However, IbarraArmenta reported lower values (11-14\%) for crushing meat produced in Sonora. It is very important to the proper moisture content to prevent deterioration of the product, because as the moisture content increases, the shelf life of these products decreases. The highest protein content was presented in the cut glove with $53.63 \%$, which was also statistically equal cutting the lizard $52.42 \%$. Conversely moisture, protein content increased with the drying process due to higher solids concentration. Konieczny et al., ${ }^{16}$ reported the behavior of the protein content of beef jerky during the drying process, which started with $19.81 \%$ at zero hours to $63.59 \%$ at the end of the process $(7 \mathrm{~h})$. On the other hand, the fat content varied between $10.62-11.22 \%$.

Table 4 Chemical composition (\%) of the finished product

\begin{tabular}{llllll}
\hline Cut & Humidity & Grease & Protein & Carbohydrates & Minerals \\
\hline Neck & $28.09^{\mathrm{a}}$ & 10.62 & $51.70 \mathrm{~b}$ & 3.09 & 6.5 \\
Glove & $24.65^{\mathrm{b}}$ & 11.22 & $53.65^{\mathrm{a}}$ & 5.03 & 5.45 \\
Lizard & $26.36^{\mathrm{ab}}$ & 10.85 & $52.42^{\mathrm{ab}}$ & 4.14 & 6.23
\end{tabular}

a, b, different literal within each column indicates significant difference ( $p 0.05)$.

\section{Conclusions}

The cut glove filed easier for moisture removal. The lizard Court presented the highest yields. With regard to the chemical composition of the finished product, the cut glove had the highest protein content and lower moisture than other cuts. The three courts evaluated represent a viable option for drying and crushing meat processing, in addition to being low-cut marketing fresh, can be used for the manufacture of various products and thus give them added value.

\section{Acknowledgements}

We thank the National Technology of Mexico and the Higher Technological Institute of Guasave, for the support received for the project, in addition to livestock company Rubios SPR de RL appreciated, for their willingness to link research and development 


\section{Conflicts of interest}

The author declares there are no conflicts of interest.

\section{Funding details}

None.

\section{References}

1. Rahman MS, Mothershaw A, Mahgoub O, et al. Physico-Chemical and Microbial Characteristics of Dried Meat Processed by Different Methods. International Journal of Food Engineering. 2005;1(2).

2. Choi JH, Jeong JY, Han DJ, et al. Effects of pork / beef casings on various levels and quality properties of semi-dried jerky. Meat Science. 2008;80:278-286.

3. Ibarra-Armenta AS, Valdez-Urias DB, Zamorano-García L, et al. Study and Improvement of the drying process beef Carne Seca and Machaca Sonora style. I work thesis, conducted in the Research Area Meat Products Division of Food Technology of Animal Origin. ICAS, AC; 2001.

4. Han-Sul Y, Young-Hwa H, Tea Seon-Gu-Boo P. The physicochemical and microbiological Characteristics of pork jerky in comparison to beef jerky. Meat Science. 2009;82:289-294.

5. McLelland MR, Lind LR, Kime RW. Determinations Hue angle and statical analysis for multiquadrant Hunter L,a,b data. Journal of quality. 1995;18:235-240.

6. Valiente BA. Problems balance of matter and energy in the food industry. $2 \mathrm{~d}$ ed. LIMUSA Noriega Editores publishing group. 2012
7. AOAC. Official Methods of Analysis. 17th edition. Association of Official Analytical Chemists International. Gaithersburg, MD. USES. 2000.

8. Coleman LW, Hickson RE, Schreurs NM, et al. Carcass Characteristics and meat quality of Hereford steers sired born to beef-cross-dairy and Angus breeding cows. Meat Science. 2016;121:403-408.

9. Priolo A, Micol D, Agabriel J. Effects of grass feeding systems on ruminant meat color and fl avour. A review. Animal Research. 2001;50(3):185-200.

10. Judge M, Aberle E, Forrest J, et al. Principles of Meat Science. Dubuke (Iowa) and Kendall Hunt Publishing. 1989. p 125-133.

11. Lawrie RA. Meat Science. 4th edn. Editorial Acribia, Zaragoza Spain. 1998.

12. Kucerová I, Marek S, Banout J. Solar Drying and Sensory Attributes of Eland (Taurotragus oryx) Jerky. Journal of Food Quality. 2018. 10 p.

13. Tzou-Chi H, Wai-Kit N. Intermediate-Dehydrated Meat and Meat Moisture. Meat Science and Applications. In: Hui YH, Wai-Kit N, Rogers RW, editors. Marcel Dekker, Inc., New York. 2001. p. 408-447.

14. Badui DS. Food Chemistry. 4th edn. Pearson Education Mexico. Edo de Mexico. Cap 1 2006. P. 1-28.

15. Harper NM, Getty KJK, Boyle EAE. Evaluation of sample preparation methods for water activity determination in beef jerky and kippered: A research note. Meat Sci. 2010;86(2):527-528.

16. Konieczny P, Stangierski J, Kijowski J. Physical and chemical Characteristics and acceptability of beef jerky style home. Meat Science. 2007;76:253-257. 